\title{
Plasma lipid pattern and red cell membrane structure in $\beta$-thalassemia patients in Jakarta
}

\author{
Seruni K. U. Freisleben, ${ }^{1,2}$ Jenny Hidayat, ${ }^{1}$ Hans-Joachim Freisleben, ${ }^{1}$ Soehardjo Poertadji, ${ }^{2}$ Budi Kurniawan, ${ }^{2}$ \\ Na Peng. Bo, ${ }^{2}$ Sri Handayani, ${ }^{1,3}$ Pustika A. Wahidiyat,${ }^{4}$ Rondang R. Soegianto ${ }^{5}$ \\ ${ }^{1}$ Postgraduate Study Program Biomedical Sciences, Faculty of Medicine, Universitas Indonesia, Jakarta, Indonesia \\ ${ }^{2}$ Department of Physics, Faculty of Mathematics and Natural Sciences, Universitas Indonesia, Jakarta, Indonesia \\ ${ }^{3}$ Department of Chemistry, Faculty of Mathematics and Natural Sciences, Universitas Indonesia, Jakarta, Indonesia \\ ${ }^{4}$ Department of Child Health, Thalassemia Center, Dr. Cipto Mangunkusumo Hospital, Jakarta, Indonesia \\ ${ }_{5}^{5}$ Department of Biochemistry and Molecular Biology, Faculty of Medicine, Universitas Indonesia, Jakarta, Indonesia
}

\begin{abstract}
Abstrak
Latar belakang: Kami melakukan penelitian selama 10 tahun terakhir untuk mendapatkan gambaran yang komprehensif mengenai kelebihan besi, stres oksidatif, dan kerusakan sel pada pasien talasemia di Jakarta.

Metode: Dari sampel darah 15 pasien yang bergantung transfusi (kelompok T), 5 pasien yang belum ditransfusi (kelompok $N$ ) dan 10 kontrol (kelompok C) dilakukan analisis plasma dan membran eritrosit yang diisolasi dan strukturnya diteliti dengan spekroskopi electron paramagnetic resonance (EPR) menggunakan doxyl-stearic acid dan maleimido-proxyl spin lable. Data statistik dianalisis dengan ANOVA.

Hasil: Terdapat nilai trigliserida lebih tinggi dan nilai kolesterol plasma lebih rendah pada penderita talasemia dibandingkan dengan kontrol. Kadar vitamin E (kelompok C: 21.8 vs T: $6.2 \mu \mathrm{mol} / \mathrm{L}$ ) dan reactive thiols (C: 144 vs. T: 61 umol/L) jauh lebih rendah pada pasien yang bergantung-transfusi. Tanda-tanda stres oksidatif (MDA, C: 1.96 vs. T: 9.2 umol/L) dan kadar transaminase dalam serum sangat tinggi. Pasien belum ditransfusi memperlihatkan sedikit tanda-tanda terjadinya stres oksidatif, tetapi tidak terdapat tanda-tanda yang berarti adanya kerusakan jaringan atau sel. Parameter membran sel darah merah dari spektroskopi electron paramagnetic resonannce (EPR) menunjukkan hasil yang sangat berbeda-beda untuk setiap kelompok. Pada pasien bergantung-transfusi, struktur membran sel darah merah serta gradien polaritas dan fluiditas dalam domain lipid menunjukkan rusak; kapasitas mengikat protein tiol di dalam membran lebih rendah dan statis.
\end{abstract}

Kesimpulan: Pada pasien bergantung transfusi, terdapat hubungan antara perubahan pola plasma lipid dan tanda-tanda stres oksidatif dengan kerusakan struktur membran darah merah, yang diukur dengan spektroskopi EPR menggunakan spin-labels lipid dan protein-thiol. (Med J Indones 2011; 20:178-84)

\begin{abstract}
Background: Over the last 10 years, we have investigated thalassemia patients in Jakarta to obtain a comprehensive picture of iron overload, oxidative stress, and cell damage.

Methods: In blood samples from 15 transfusion-dependent patients (group T), 5 non-transfused patients (group N) and 10 controls (group C), plasma lipids and lipoproteins, lipid-soluble vitamin E, malondialdehyde (MDA) and thiol status were measured. Isolated eryhtrocyte membranes were investigated with electron paramagnetic resonance (EPR) spectroscopy using doxyl-stearic acid and maleimido-proxyl spin lables. Data were analyzed statistically with ANOVA.

Results: Plasma triglycerides were higher and cholesterol levels were lower in thalassemic patients compared to controls. Vitamin E, group C: 21.8 vs T: $6.2 \mu \mathrm{mol} / \mathrm{L}$ ) and reactive thiols (C: $144 \mathrm{vs.} \mathrm{T:} 61 \mu \mathrm{mol} / \mathrm{L}$ ) were considerably lower in transfused patients, who exert clear signs of oxidative stress (MDA, C: $1.96 \mathrm{vs} \mathrm{T:} 9.2 \mu \mathrm{mol} / \mathrm{L}$ ) and of tissue cell damage, i.e., high transaminases plasma levels. Non-transfused thalassemia patients have slight signs of oxidative stress, but no significant indication of cell damage. Erythrocyte membrane parameters from EPR spectroscopy differ considerably between all groups. In transfusion-dependent patients the structure of the erythrocyte membrane and the gradients of polarity and fluidity are destroyed in lipid domains; binding capacity of protein thiols in the membrane is lower and immobilized.

Conclusion: In tranfusion-dependent thalassemic patients, plasma lipid pattern and oxidative stress are associated with structural damage of isolated erythrocyte membranes as measured by EPR spectroscopy with lipid and proteinthiol spin labels. (Med J Indones 2011; 20:178-84)
\end{abstract}

Key words: electron paramagnetic resonance spectroscopy, erythrocyte membrane, lipoproteins, oxidative stress, thalassemia, plasma lipids.

Thalassemias are inborn disorders of the globin chain synthesis and the most frequent single gene derived inherited diseases in the world. More than $3 \%$ of the world's population carry thalassemia genes, with very high incidence in South East Asia. Various mutations and deletions on $\alpha$ - and the $\beta$-globin gene clusters (more than 100 in the $\alpha$ - and about 200 in the $\beta$-gene are known) diminish globin chain synthesis to different extent and result in thalassemia trait or clinical pictures of thalassemia. In the Indonesian population the frequency of mutant $\beta$-globin genes appears to be about $6-10 \%$. The $\beta$-thalassemic phenotype shows wide 
variations between transfusion-dependent thalassemia major, different severities of thalassemia intermedia and thalassemia minor or trait. The clinical picture is determined by the combination of two different alleles and co-inheritance of various kinds of thalassemias and related hemoglobin anomalies. ${ }^{1}$

The clinical picture of thalassemias is dominated by chronic anemia caused by ineffective erythropoiesis, intra-andextramedullaryhemolysis, andby ironoverload due to generally increased intestinal iron absorption in thalassemia and following additional blood supply to transfusion-dependent patients. Imbalanced excessive globin chains tend to precipitate near the red blood cell membrane causing either intramedullary cell death or increased clearance of the erythrocyte from peripheral circulation. Hemochromes, heme, and released iron contribute to the damage conferred by the precipitated globin chains (inclusion bodies). ${ }^{2}$ Iron and certain ironcontaining low molecular weight compounds play a crucial role to generate reactive oxygen species (ROS) and free radicals, which are likely to damage cellular and sub-cellular structures, especially membranes in various tissues, ${ }^{3}$ to cause metabolic dysfunction ${ }^{4}$ and alteration of the plasma lipid pattern with high triglyceride and low cholesterol levels. ${ }^{5}$ In the frame of our previous studies, we reported on hematology, iron overload, imbalanced antioxidant status ${ }^{6}$ and changes in characteristics of isolated $\mathrm{RBC}$ membranes in thalassemic patients in Jakarta. ${ }^{7}$

Now, we compare the plasma lipid pattern under oxidative stress with parameters of isolated RBC membranes from thalassemic patients measured with electron paramagnetic resonance spectroscopy using doxyl-stearic acid spin labels and thiol-reactive $\mathrm{N}$-proxyl-maleimide spin label.

\section{METHODS}

\section{Subjects}

Fifteen transfusion-dependent $\beta$-thalassemia major patients from Cipto Mangunkusumo General Hospital, in an age range of 11 to 25 years were investigated (group T). Ten controls (group C) were voluntary students without diagnosis or clinical signs of thalassemia in the same age range (up to 25 years of age). Since it is difficult to find thalassemia intermedia patients who have not yet been transfused in the same age range as in the two other groups, the age range of group $\mathrm{N}$ (five non-transfused patients) is from 7 to 14 years. The groups had random sex distribution. All participants were non-smokers, did not suffer obviously from other metabolic diseases or acute infections, and indicated not to receive specific vitamin supplementation or medication other than transfusion and chelation.

The study was approved by the Ethical Committee of the Faculty of Medicine, Universitas Indonesia and all blood samples from controls and patients were obtained on fully informed consent. Citrate blood $(20 \mathrm{~mL})$ and ethylenediaminetetraacetate (EDTA) blood $(5 \mathrm{~mL})$ were collected from each subject. From transfusiondependent patients, blood samples were collected just before they received a new transfusion. If necessary, further information about the patients, transfusion and chelation regimens, how long the patients had already been transfused and clinical status etc. were taken from the patients' ward records at Cipto Mangunkusumo General Hospital in Jakarta. The study and survey of thalassemia patients has been conducted over the last ten years. The first approval of the long-term study "Oxidative stress in thalassemia patients in Jakarta" had been in 1999.

\section{Blood analysis}

Hemoglobin $(\mathrm{Hb})$-screening was performed in the laboratory of the Thalassemia Ward with a VARIANT Hemoglobin Testing System. All other hematological parameters were measured from citrate blood $(10 \mathrm{~mL})$ in laboratories of the Faculty of Medicine Univesritas Indonesia (UI) according to standard methods or as described. $^{4-7}$

\section{Preparation of RBC membranes}

Fresh blood samples from healthy controls or thalassemia patients were supplied by the Thalassemia Ward of Cipto Mangunkusumo General Hospital in Jakarta for the preparation of isolated RBC membranes in the laboratory of the Deapartment of Biochemistry and Molecular Biology Faculty of Medicine UI. Isolated RBC membranes were prepared and lyophilized as described. ${ }^{6}$

\section{EPR spectroscopy}

Spin labels were purchased from Sigma-Aldrich (Sydney, Australia) and used to characterize isolated red cell membrane (ghosts): 5-doxyl-stearic acid and 16-doxyl-stearic acid (doxyl- = 4,4-dimethyl3-oxazolinyloxy-=4,4-dimethyl-oxazolidine-Noxyl-). The spin label 3-maleimido-proxyl (proxyl- = 2,2,5,5-tetramethyl-1-pyrrolidinyloxy- $=2,2,5,5$ tetramethylpyrrolidine-N-oxyl-) is analogous to the classical thiol blocking reagent N-ethylmaleimide (NEM). This spin label reacts with thiols of membraneintegral or membrane-associated proteins by covalent binding in the same way as NEM. ${ }^{6}$ 
From the first derivatives of 3-maleimido-proxyl signals the ratio of the height of the midfield line $(h)$ and the height of the high-field line $\left(h_{-1}\right)$ were calculated $\left(h_{0} / h_{-1}\right) \cdot{ }^{6}$ The low-field line $\left(h_{+1}\right)$ tends to separate into two peaks from immobilized $\left(h_{+11}\right)$ and from mobile $\left(h_{+1 \mathrm{M}}\right)$ populations. Since the 3-maleimido-proxyl spin label is covalently bound to protein thiols, it provides information about their mobile or immobilized environment in membrane proteins, calculated as the $\left(h_{+1 \mathrm{I}}\right) /\left(h_{+1 \mathrm{M}}\right)$ ratio. $^{6}$

From the first derivatives of the EPR signals of 5-doxyland 16-doxyl-stearic acids, order parameters $s$ were calculated, moreover hyperfine coupling constant $a_{\mathrm{N}}$ and rotational correlation times from 16-doxyl-stearic acid. ${ }^{6}$

\section{EPR measurement}

Membrane labeling and measurement of spectra were carried out as decribed. A JEOL RE series, JES-RE2X ESR spectrometer with a JEOL X-band microwave in the Department of Physics, Faculty of Mathematics and Natural Sciences UI Depok was used for EPR spectroscopy. All spectra were collected under the same instrumental settings. Spectra and equations were resented in detail. ${ }^{6}$

\section{Data analysis}

Data were presented as mean values and standard deviations and were analyzed using ANOVA test with the aid of STATS ' 98 , Internet version 1.1, Decision Analyst, Inc. $\mathrm{p}<0.05$ was taken as the limit of statistical significance.

\section{RESULTS}

\section{Serum lipids \& peroxidation products}

Compared to controls, triglycerides are more than 1.5 -fold higher in thalassemic patients as shown in Table 1. [Differences between groups N $(169 \mathrm{mg} / \mathrm{dL})$, $\mathrm{T}(179 \mathrm{mg} / \mathrm{dL})$ and controls $(103 \mathrm{mg} / \mathrm{dL})$ are highly significant]. Total cholesterol, LDL, and HDL are lower in non transfused patients than in controls and repeated transfusions brought these parameters even lower.

The LDL/HDL ratio is significantly lower in transfused patients compared to non transfused and control and the ratio of total cholesterol to HDL do not strongly differ from controls and non-transfused patients, but do in transfusion-dependent patients (Table 1). Peroxidation products of (poly)-unsaturated fatty acids in serum and in membrane phospholipids measured as thiobarbiturate-reactive substances (TBARS) are presented as malondialdehyde (MDA). Values are 1.96 $\mu \mathrm{mol} / \mathrm{L}$ in controls, $5.0 \mu \mathrm{mol} / \mathrm{L}$ in non-transfused, and $9.2 \mu \mathrm{mol} / \mathrm{L}$ in transfused patients.

Table 1. Plasma lipid pattern, lipoproteins, and lipidperoxidation

\begin{tabular}{llll}
\hline & $\begin{array}{l}\text { Controls } \\
\mathrm{n}=10\end{array}$ & $\begin{array}{l}\text { Non-transfused } \\
\mathrm{n}=5\end{array}$ & $\begin{array}{l}\text { Transfused } \\
\mathrm{n}=15\end{array}$ \\
\cline { 2 - 4 } & Mean $(\mathrm{SD})$ & Mean $(\mathrm{SD})$ & Mean $(\mathrm{SD})$ \\
\hline Triglycerides $[\mathrm{mg} / \mathrm{dL}]$ & $103(49.5)$ & $169(51.3)^{* *}$ & $179(44.3)^{* *}$ \\
Total cholesterol $[\mathrm{mg} / \mathrm{dL}] ;$ & $184(27.4)$ & $172(84.9)^{+}$ & $129(26.1)^{* *}$ \\
LDL $[\mathrm{mg} / \mathrm{dL}]$ & $104(25.3)$ & $79(30.9)^{*}$ & $65(34.1)^{* *}$ \\
HDL $[\mathrm{mg} / \mathrm{dL}]$ & $56(16.5)$ & $41(15.1)^{*+}+$ & $21(6.7)^{* *}$ \\
LDL/HDL & 1.9 & 1.9 & 3.1 \\
Tot.Chol/HDL & 3.3 & 4.2 & 6.1 \\
MDA $[\mu \mathrm{mol} / \mathrm{L}]$ & $1.96(1.46)$ & $5.0(4.18) *$ & $9.2(6.0)^{* *}$ \\
\hline
\end{tabular}

$* \mathrm{p}<0.05$ vs control; ** $\mathrm{p}<0.01$ vs control; $+\mathrm{p}<0.05$ transfused vs non transfused.

\section{Alpha tocopherol}

Vitamin E ( $\alpha$-tocopherol) is $21.8 \mathrm{mM}$ in controls $(\mathrm{C})$, $20.9 \mathrm{mM}$ in non-transfused patients, and $6.2 \mathrm{mM}$ in group $\mathrm{T}=$ transfused patients (Fig. 1). The differences between transfusion-dependent patients and the other two groups are higly significant.

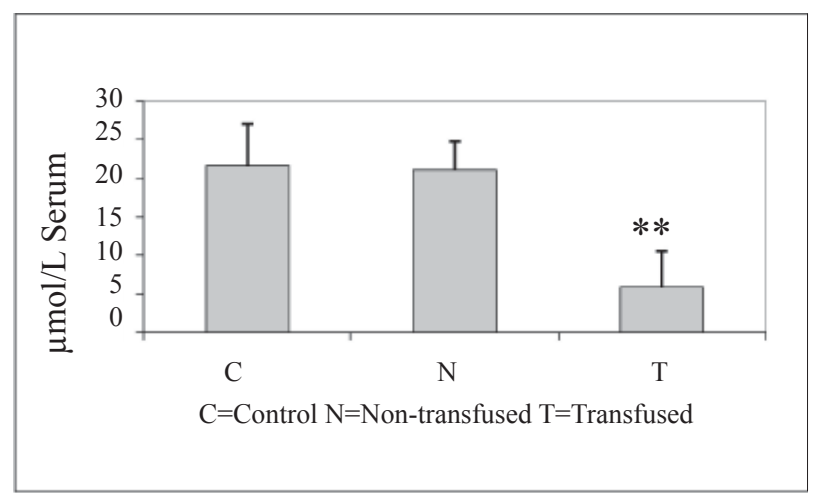

Figure 1. $\alpha$-tocopherol level in thalassemia patients and healthy subjects; $* * P<0.01$ vs control

\section{Serum transaminases}

Serum transaminases are significantly higher in all transfused patients: glutamate-oxaloacetate transaminase (SGOT) 39.6; 59.4; and 110.6 IU/L in control, non transfused, and transfused patients, respectively $(\mathrm{p}<0.01)$; glutamate-pyruvate transaminase (SGPT) $32.4 ; 46.7$ and $90.2 \mathrm{IU} / \mathrm{L}$, respectively.

\section{Thiol status in plasma and in RBC membrane}

Plasma thiols decreased from $144 \mu \mathrm{mol} / \mathrm{L}$ in controls to $88 \mu \mathrm{mol} / \mathrm{L}$ in non-transfused and further to $61 \mu \mathrm{mol} / \mathrm{L}$ in transfused patients. Protein thiols [nmol SH/mg prot] were 2.0 in controls, 1.3 in non-transfused and 1.0 in transfusion-dependent patients $\mathrm{T}$ (Table 2). 
Table 2. Reactive thiols (SH)

\begin{tabular}{llll}
\hline & $\begin{array}{l}\text { Controls } \\
\mathrm{n}=10\end{array}$ & $\begin{array}{l}\text { Non-transfused } \\
\mathrm{n}=5\end{array}$ & $\begin{array}{l}\text { Transfused } \\
\mathrm{n}=15\end{array}$ \\
\cline { 2 - 4 } & Mean $(\mathrm{SD})$ & Mean $(\mathrm{SD})$ & Mean $(\mathrm{SD})$ \\
\hline $\begin{array}{l}\text { Plasma -SH }[\mu \mathrm{mol} / \mathrm{L}] \\
\text { mean }(\mathrm{SD})\end{array}$ & $144(19.3)$ & $88(43.1) *$ & $61(29.7) * *$ \\
Protein-SH[nmol/mg prot.] & $2.0(0.3)$ & $1.3(0.87) *$ & $1.0(0.53) * *$ \\
$* \mathrm{p}<0.05$ vs control; $* * \mathrm{p}<0.01$ vs control; & & \\
& & &
\end{tabular}

Parameters determined from 3-maleimido-proxyl (=NEM$\mathrm{SL}$ ), which reacts covalently with membrane thiols provide information about proteins associated with or integrated into the membrane. Binding capacity is expressed through $h_{\mathrm{o}} / h_{-1}$ ratios. In controls $h_{0} / h_{-1}$ ratio was 1.7 , in non-transfused patients 2.2 and in transfused patients it was 1.4 (Fig. 2).

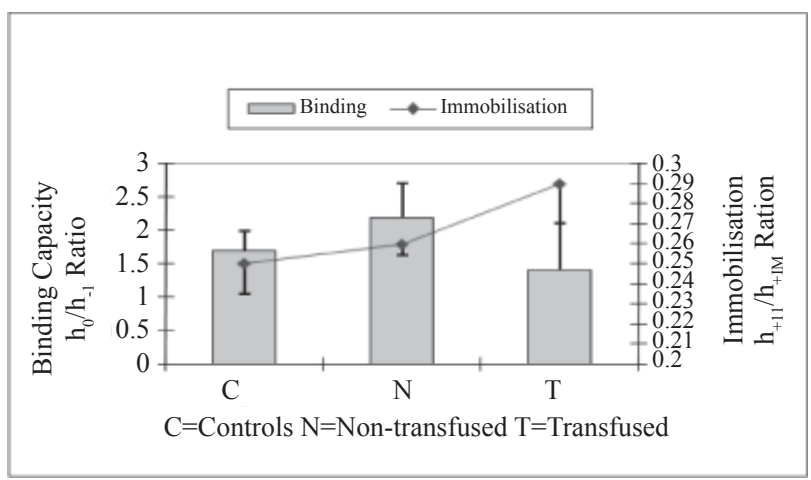

Figure 2. RBC membrane thiols

Once bound to membrane thiols the spin label reports on its environment by splitting of the low field line into mobile (M) and immobilized (I) populations. Increase in I/M ratio $\left(h_{+1 \mathrm{I}}\right) /\left(h_{+1 \mathrm{M}}\right)$ means immobilization of the spin label and thus of the environment of cystein thiols in membrane proteins. Controls are 0.245, nontransfused patients $0.265(\mathrm{p}<0.05)$, and transfused patients 0.29 ( $p<0.01 v s$. control) (Fig 2). In other words, immobilization is higher in non-transfused patients than in controls and in transfusion-dependent patients significantly higher than in the two other groups.

\section{Order parameters of RBC membranes}

Order parameters from 5-doxyl-stearic acid, which reports from the polar/sub-polar region of the membrane, are 0.699 in controls and 0.733 in nontransfused patients (Fig. 3a). In the group of transfused patients order parameters from 5-doxyl-stearic acid are 0.638. Differences of all groups versus controls are highly significant $(\mathrm{p}<0.01)$, also between nontransfused (group N) and the transfused group (T).

Order parameter $s$ from 16-doxyl-stearic acid (Figure 3b), which provides information on the inner hydrophobic region of the membrane, is 0.239 in controls and 0.272 in non-transfused patients. In the group of transfused patients order parameters from 16-doxyl-stearic acid are 0.297 (group T) (Fig. 3b). Differences of all groups versus controls are highly significant $(p<0.01)$, those between the other groups and transfusion-dependent patients (group $\mathrm{T})$ are significant $(\mathrm{p}<0.05)$, whereas differences between non-transfused patients (group $\mathrm{N}$ ) and controls are not. The order parameters obtained from the inner membrane region are consecutively higher in non-transfused and transfusion-dependent patients than in controls.
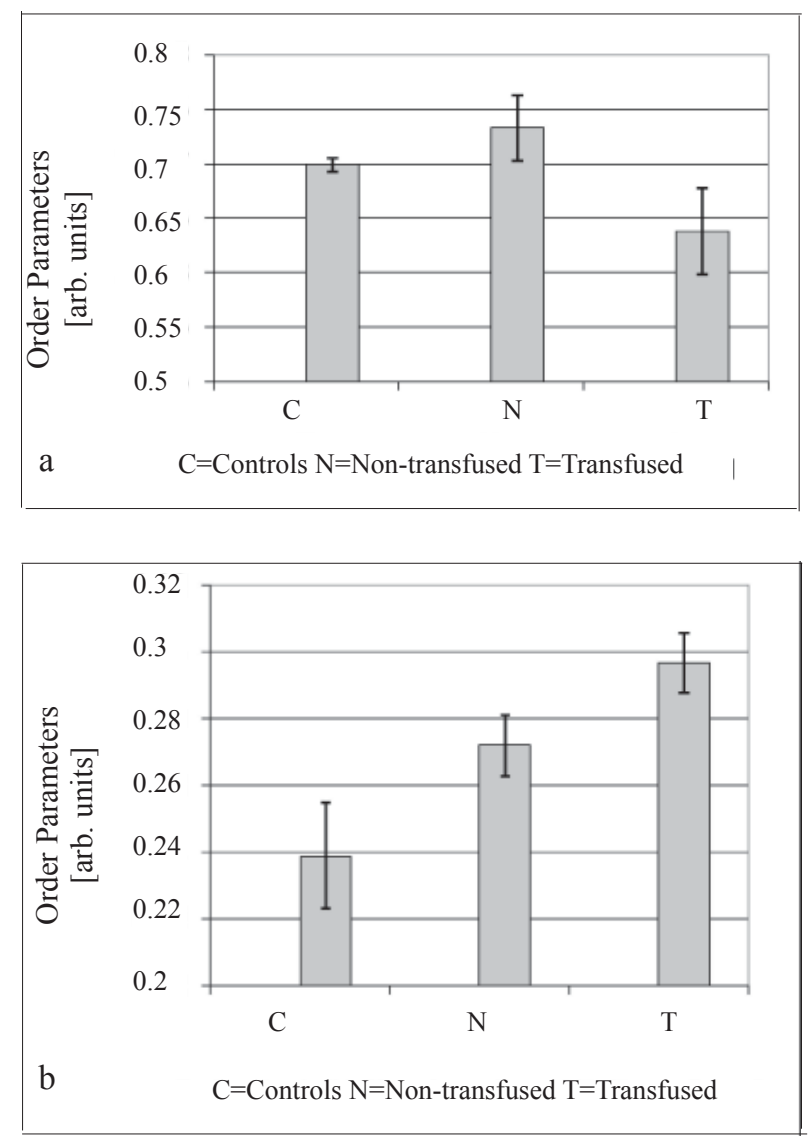

Figure 3. Order parameter of 5-doxyl stearate. ( $\alpha$ ) and 16-doxyl stearate (b)

Table 3. Rotational correlation times $\left(\mathrm{T}_{\mathrm{R}}\right)$ and Hyperfine coupling constants $\left(\mathrm{a}_{\mathrm{N}}\right)$

\begin{tabular}{llll}
\hline & $\begin{array}{l}\text { Controls } \\
\mathrm{n}=10\end{array}$ & $\begin{array}{l}\text { Non-transfused } \\
\mathrm{n}=5\end{array}$ & $\begin{array}{l}\text { Transfused } \\
\mathrm{n}=15\end{array}$ \\
\cline { 2 - 4 } & Mean (SD) & Mean (SD) & Mean (SD) \\
\hline$T_{R}\left[10^{-10} \mathrm{~s}\right] / 16-\mathrm{DSA}$ & $24(1.615)$ & $23(2.265)^{+}$ & $29(2.906)^{* *}$ \\
$\mathbf{a}_{N}[$ gauss $] / 16-D S A$ & $13.2(0.15)$ & $13.2(0.13)^{+}$ & $13.9(0.3) * *$ \\
\hline
\end{tabular}

16-DSA $=16$-doxyl stearic acid; $* * \mathrm{p}<0.01$ vs control; $+\mathrm{p}<0.05$ vs transfused

Rotational correlation times $T_{R}$ calculated from 16doxyl-stearic acid spin label do not differ significantly between controls and non-transfused patients, whereas 
higher values in transfusion-dependent patients are highly significant $v s$. controls. (Table 3 ).

\section{Membrane polarity}

The hyperfine coupling constant $a_{\mathrm{N}}$ from 16-doxylstearic acid is 13.2 gauss in the control group, 13.2 gauss in non-transfused, and 13.9 gauss in transfused patients. The difference of group $\mathrm{T}$ versus controls is highly significant $(p<0.01)$ (Table 3 ). Hyperfine coupling constant $a_{\mathrm{N}}$ is a measure of membrane polarity, which is significantly higher in transfusion-dependent patients than in controls and non-transfused patients.

\section{DISCUSSION}

\section{Non-transfused patients}

In non-transfused patients, triglycerides are significantly higher and HDL-cholesterol is sigificantly lower than controls. In an ethnic study, erythrocyte membrane fluidity was associated mainly with triglyceride levels. ${ }^{8}$

In general, thalassemic patients exert decreased levels in antioxidant vitamins, especially lipid-soluble vitamin $\mathrm{E}$ and water-soluble vitamin C. ${ }^{5}$ In our non-transfused patients, MDA as an indicator of lipid peroxidation is more than doubled as compared to controls although vitamin $\mathrm{E}$, the major membrane protecting compound is only slightly decreased. Increased LPO in nontransfused patients could be the major reason for a $40 \%$ lower lipid unsaturation index reported in RBC membranes of heterozygous $\beta$-thalassemia patients. ${ }^{9}$

Plasma protein status, in general, and activities of plasma transamninases are not altered significantly in non-transfused patients. However, reactive plasma thiols, a protein related indicator of oxidative stress, are significantly lower than in controls. Briefly, most titratable thiols are located in the amino acid cystein comprising both glutathione-SH and protein-SH. Loss of thiols means primarily oxidation of cystein to cystin with disulfide brigde (-S-S-) formation in glutathione and proteins and concomitant loss of function.

Membrane thiols are almost exclusively located in proteins. Integral and membrane-associated proteins contribute to the fluidity or rigidity of the membrane through oxidation of thiols forming either mixed disulfides or linking two cysteins to non-physiological intra- or inter-molecular cystins leading to aggregations or conformational changes. Thiol-reactive NEM spin label is very hydrophobic and thus reacts exclusively with thiols in the hydrophobic environment of the membrane, which comprise about $60 \%$ of cysteins in $\mathrm{RBC}^{7}$ The EPR spectrum allows for interpretation of the binding capacity of protein thiols in hydrophobic environment and provides information about the immobilization of the cystein-bound spin label. Binding capacity was higher in our non-transfused patients, but the population of immobilized spin labels was slightly higher than in controls indicating rigidified environment.

This picture of membrane proteins mirrors the membrane order parameters of non-transfused patients: they are higher than controls. Stearic acid spin labels (SA-SL) report from lipid domains and lipid-protein interfaces in RBC membranes: viscosity is higher both, in polar (5-doxyl-SA) and hydrophobic (16-doxyl$\mathrm{SA})$ regions. Hyperfine coupling constants ( $a_{\mathrm{N}}$ values) and rotational correlation times $T_{R}$ do not differ from controls indicating no changes in polarity and freedom of molecular rotation in RBC membranes from nontransfused patients. In other words, although membranes are more rigid in non-transfused patients than in controls, freedom of molecular motion and the polarity gradient across the membrane are still in the normal range.

\section{Transfusion-dependent patients}

The above picture differs considerably in transfusiondependent patients. The plasma lipid pattern shows high triglycerides, whereas cholesterol levels are extremely low, especially in HDL. Thus, ratios of LDL/HDL and total cholesterol/HDL are pathologically high.

The vitamin status in transfusion-dependent patients shows tremendous depletion in lipid-soluble vitamins, e.g. vitamin $\mathrm{E}$ is less than $30 \%$ of controls. In addition to its protection against lipidperoxidation (LPO), vitamin $\mathrm{E}$ has multiple stabilizing effects on membrane structure. Lipid peroxidation is almost five times higher in transfusion-dependent patients than in controls indicating elevated oxidative stress.

Serum transaminases increase tremendously in transfusion-dependent patients indicating massive cell membrane damage in tissues, especially - but not only in liver. It is concluded that iron overload and oxidative stress gradually damage tissues in liver, pancreas and myocardium. ${ }^{5}$ On the other hand, it was concluded that liver cell damage contributes to the changes in plasma lipid pattern and lipoprotein composition in thalassemic patients. ${ }^{10}$

Furthermore, the thiol status in plasma and in plasma proteins and in $\mathrm{RBC}$ membrane decreases in transfusiondependent patients to about $50 \%$ of controls, which indicates oxidative stress in all blood compartments, along with conformational changes and loss of function in proteins. Low levels in reactive thiols indicate that glutathione status as well as plasma protein cysteins are impaired, which means both, function and repair system 
are not intact. The spin label binding to membrane thiols shows lower binding capacity and higher immobilization of membrane protein cysteins in transfusion-dependent patients than in controls and non-transfused patients.

This picture is comparable to anisotropy of 16doxyl SA, i.e., freedom of motion of the spin label is restricted and thus, rotational correlation times are higher. This means, the picture matches between two different parameters: increased order parameter indicates decreased fluidity or increased viscosity, which decreases the freedom of rotational motion. It should be kept in mind that the terms "rigidity" or "viscosity" are inversely proportional to "fluidity"; i.e., increased rigidity or viscosity means decreased fluidity and vice versa.

Order parameters of 5-doxyl-stearic acid are lower than in controls and non-transfused patients demonstrating destruction of the membranes in transfusion-derendent patients. In other words, lower cholesterol content in plasma of transfused patients is associated with less ordered structure and increased fluidity in the polar region of isolated erythrocyte membranes, possibly due to less membrane-bound cholesterol. The membrane stabilizing effect may be especially expressed in the region just under the polar headgroups, where position C5 of 5-doxyl-stearic acid is located in the polar-tohydrophobic interface. The highly ordered region at the polar interface exerts the highest energetic barrier of the membrane. ${ }^{11}$

In transfusion-dependent patients, we observe a countercurrent phenomenon: whereas rigidity is higher than normal in the inner hydrophobic region of the membrane, the polar interface becomes more disordered and fluid, which means the order gradient across the membrane is destroyed. In controls, there is a high structural order gradient across the RBC membrane, expressed in threetimes higher order parameters in the outer polar regions and higher fluidity in the hydrophobic inner membrane region. Loss of this physiological structural order and the concomitant loss of the fluidity gradient across the membrane is mainly due to the loss of structural elements in membranes, primarily loss of cholesterol and tocopherol.

Concerning lipid-protein interaction in RBC membranes of transfused patients, our interpretation is that there are strong phase separation tendencies between protein-rich and lipid domains with loss in structural integrity and homogeneity. This is not unexpected because frequently transfused thalassemic patients have mixtures of endogenous and exogenous blood cells. Phase separation may lead to inhomogeneous $\mathrm{RBC}$ membranes with reorientation of integral proteins to the periphery (or vice versa) and formation of blebs from blood cell membranes in thalassemia. ${ }^{12}$

Hyperfine coupling constants from 16-doxyl SA spin label indicate an increase in polarity in the inner hydrophobic region of thalassemic RBC membranes. This means conformational changes in membrane proteins and lipids with formation of inverse phases and hydrophilic pores, in other words, leaky mambranes. ${ }^{13}$ Band-3 degradation may strongly be involved in the formation of such membrane leaks. To further characterize RBC membrane proteins in thalassemic patients band 3 proteins, calcium-ATPase, and glucose transport have been investigated; results will be published, separately.

Altered plasma lipid patterns have been reported in thalassemia major patients, ${ }^{14,15}$ whereas a Greek study only found significantly low HDL-cholesterol in their thalassemic patients. ${ }^{16}$

In other diseases, serum lipid pattern, phospholipid fatty acid composition, and fatty acid unsaturation index, vitamin E content and LPO correlated with the composition and structure of erythrocyte membranes. ${ }^{17,18}$ This matches our own findings. However, in this context, it must be mentioned that - different from other diseases - thalassemic hemoglobin plays a deleterious role in the destruction of RBC membranes. Hemoglobin electrophoresis pattern of transfusion-dependent $\beta$-thalassemia patients was investigated, recently. ${ }^{19}$

It is concluded that in non-transfused patients, $\mathrm{RBC}$ membranesaremoderatelyrigidified,mainlyduetoincreased plasma triglycerides and increased lipidperoxidation which may decrease the lipid unsaturation index. In transfusion-dependent patients membrane integrity appears to be destroyed with loss of essential polarity and fluidity gradients and loss of the energetic barrier. Phospholipids and integral membrane proteins are involved in the leakiness of membranes, loss of stabilizing components such as cholsterol and tocopherol along with oxidative stress and LPO induces membrane fragility and hemolysis. This situation is mirrored by the plasma lipid pattern in transfused patients, which obviously influences the composition and structure of the RBC membrane. Since regular transfusions appear to play an essential role in membrane destruction and disintegration, protection of RBC membrane structure and integrity (e.g., with vitamin $\mathrm{E}$ and iron chelators) and moderate transfusion regimens with extended intervals have become the aims of therapeutic intervention. ${ }^{20}$

\section{Acknowledgments}

This study was supported by the URGE Project of the Indonesian Government. The authors are furthermore gratefully obliged Dr. R. Wirawan and Dr. S. Kusnandar, 
Department of Clinical Pathology, Cipto Mangunkusumo General Hospital, and to Dr. DHS Dillon, SEAMEOTROPMED Nutrition, Faculty of Medicine, Salemba, Jakarta for their cooperation and support in this study.

\section{REFERENCES}

1. Wahidiyat PAW. Faktor-faktor genetik pengubah manifestasi klinis thalassemia- $\beta / \mathrm{HbE}$ : Interaksi antara mutasi thalassemia- $\beta,-\alpha$, polimorphisme $X m n l^{-}{ }^{\mathrm{G}} \gamma$, dan SNPs pada klaster gen globin- $\beta$ [dissertation]. Jakarta, Indonesia: Faculty of Medicine, Doctoral Program Medical Sciences, Universitas Indonesia; 2009. [Indonesian].

2. Chiu DTJ, van den Berg J, Kuypers FA, Hung IJ, Wie JS, Liu TZ. Correlation of membrane lipid peroxidation with oxidation of hemoglobin variants: possibly related to the rates of hemin release. Free Rad Biol Med. 1996;21:89-95.

3. Brili SV, Tzonou AI, Castelanos SS, Aggeli CJ, Tentolouris CA, Pitsavos CE, Toutouzas PK. The effect of iron overload in the hearts of patients with beta-thalassemia. Clin Cardiol.1997;20:541-6.

4. Laksmitawati DR, Handayani S, Udyaningsih-Freisleben SK, Kurniati V, Adhiyanto C, Hidayat J, et al. Iron status and oxidative stress in $\beta$-thalassemia patients in Jakarta. BioFactors. 2003; 19:53-62.

5. Freisleben HJ, Hidayat J, Handayani S, UdyaningsihFreisleben SK, Kurniati V, Adhiyanto C, et al. Blood lipids and oxidative stress in $\beta$-thalassemia patients in Jakarta. DIGM Medical J. 2005 Jan; II(1):11-6.

6. Handayani S, Adhiyanto C, Fani IR, Hidayat J, Ratih D, Kurniati V, etal. Imbalanced antioxidant status in transfusiondependent thalassemia patients in Jakarta, Indonesia. In: Nesaretnam K, Packer L, editors. Micronutrients and Health-Molecular Biological Mechanisms. Champaign: AOCS Press; 2001. p. 290-8.

7. Udyaningsih-Freisleben S K, Kurniati V, Prasetyo PB, Handayani S, Adhiyanto C, Soegianto RR, et al. Isolated erythrocyte membranes of transfusion-dependent and nontransfused thalassemia patients in Jakarta - investigated by electron paramagnetic resonance spectroscopy. BioFactors. 2003;19:87-100.

8. Miller MA, Sagnella GA, Markandu ND, MacGregor GA. Ethnic differences in erythrocyte membrane fluidity and the association with serum triacylglycerols. Clinical Science. 2001;100: 653-8.

9. Sanghani SP, Haldankar VA. Comparative analysis of RBC membrane fatty acids, proteins and glycophorin in patients with heterozygous beta-thalassemia and iron deficiency anemia. Indian Journal of Clinical Biochemistry. 2006;21(2):28-33.

10. MaioliM, Vigna GB, Tonolo G, BrizziP, Ciccarese M,Donega $\mathrm{P}$ et al. Plasma lipoprotein composition, apolipoprotein(a) concentration and isoforms in $\beta$-thalassemia. Atherosclerosis. 1997;131:127-33.

11. Zimmer G, Bernhörster M, Pilz P, Schuchmann-Fix J. Action of b-agonists compared to cromoglycate on mononuclear cell membranes - stabilizing or destabilizing? In:Zimmer G, editor. Membrane Structure in Disease and Drug Therapy. New York: M. Dekker; 2000. p. 427-37.

12. Suriyaphol P, Malasit P, Wilairat P, Fucharoen S, Bhakdi S. Investigations into the pathogenic mechanisms responsible for the increased susceptibility to infections in thalassemic patients. The $7^{\text {th }}$ International Conference on Thalassemia and the Haemoglobinopathies; 1999 May 31-June 4; Bangkok, Thailand. Book of Abstracts S1203. p. 165.

13. Tapan G, Radhaballav B, Kajal B, Ratanlal LB. Holes on Red Blood Cell Membranes Including Thalassemia Imaged by Atomic Force Microscopy. Microscopy and Microanalysis. 2004; 10(Suppl. 02):1110-1 doi:10.1017/ S1431927604881443

14. Al-Quobaili FA, Abou Asali IE. Serum levels of lipids and lipoproteins in Syrian Patients with beta-thalassemia major. Saudi Med J. 2004 Jul;25(7):871-5.

15. Mansi KM, Aburjai TA. Lipid Profile in Jordanian Children with ß-thalassemia Major. International Journal of Hematology and Oncology (IJHO/UHOD) 2008;18(2):93-8.

16. Chrysohoou C, Panagiotakos DP, Pitsavos C, Kosma K, Barbetseas J, Karagiorga M, et al. Distribution of serum lipids and lipoproteins in patients with beta-thalassemia major; an epidemiological study in young adults from Greece. Lipids Health Disease.2004;3:3-10.

17. Vijayakumar D, Suresh K, Manoharan S. Altered pattern of lipids in plasma and erythrocyte membranes of rheumatoid arthritis patients. Indian J Clin Biochem. 2005;20(1):52-5.

18. DimeskiG,MolleeP, CarterA.IncreasedLipidConcentration Is Associated with Increased Hemolysis. Clin Chem. 2005;51(12):2425 DOI:10.1373/clinchem.2005.058644

19. Wirawan R, Setiawan S, Gatot D. Peripheral blood and hemoglobin electrophoresis pattern in beta thalassemia major patients receiving repeated blood transfusions. Med J Indones. 2004;13:8-16

20. Cazzola M, Borgna-Pignatti C, Locatelli F, Ponchio L, Beguin Y, deStefano P. A moderate transfusion regimen may reduce iron loading in $\mathrm{b}$-thalassemia major without producing excessive expansion of erythropoiesis. Transfusion. 1997;37:135-40. 